\title{
Ornithine Decarboxylase Knockout in Tapesia yallundae Abolishes Infection Plaque Formation In Vitro but Does Not Reduce Virulence Toward Wheat
}

\author{
E. Mueller, ${ }^{1}$ A. Bailey, ${ }^{2}$ A. Corran, ${ }^{1}$ A. J. Michael, ${ }^{3}$ and P. Bowyer ${ }^{4}$ \\ ${ }^{1}$ Zeneca Agrochemicals, Jeallots Hill, Berkshire, U.K.; ${ }^{2}$ Department of Biological Sciences, University of \\ Bristol, Bristol, U.K.; ${ }^{3}$ Institute of Food Research, Colney Lane, Norwich, U.K.; ${ }^{4}$ IACR-Long Ashton \\ Research Station, Department of Agricultural Sciences, University of Bristol, Long Ashton, Bristol \\ BS41 9AF, U.K. \\ Submitted 8 March 2001; Accepted 5 July 2001.
}

\begin{abstract}
A knockout strain of Tapesia yallundae lacking the single ornithine decarboxylase (ODC) allele has been created by targeted gene replacement. A central region of the ODC gene was isolated by polymerase chain reaction with degenerate oligonucleotides and used to probe a lambda genomic library. The gene was sequenced, and the encoded ODC protein sequence was shown to be similar to those from other fungi. The functionality of the $T$. yallundae ODC was confirmed by complementation of an Aspergillus nidulans mutant (puA) strain devoid of ODC activity, restoring growth in the absence of exogenous polyamines. Transformation-mediated gene replacement was used to create strains that were auxotrophic for putrescine and lack ODC coding sequences. ODC knockout strains were unable to differentiate infection structures after in vitro induction and showed an abnormal hyphal branching phenotype. Pathogenicity studies on these mutants showed that, surprisingly, they are not reduced in virulence compared with nondisrupted transformants. This suggests that the strains carrying an ODC disruption can obtain sufficient polyamines from the host plant for normal growth and differentiation and, therefore, that fungal ODC may not be a suitable target for fungicides.
\end{abstract}

Eyespot, caused by the ascomycete fungus Tapesia yallundae (previously Pseudocercosporella herpotrichoides), is a major disease of winter wheat in temperate areas of the world. In surveys of U.K. crops, over $80 \%$ of wheat fields were affected each year, with losses equivalent to $4 \%$ of total production.

Polyamines are ubiquitous low-molecular-weight cationic organic compounds. A number of polyamines occur naturally. The most widely distributed ones are the diamine putrescine (1,4-diaminobutane), triamine spermidine (4-azaoctane-1,8diamine), and tetraamine spermine (4,9-diazadodecane-1,12diamine) (Tabor and Tabor 1985). These are the major polyamines in eukaryotes, including fungi. The enzymes involved in polyamine biosynthesis have been purified and character-

Corresponding author: P. Bowyer; Telephone: +44 1275 549297;

Fax: +44 1275 394281; E-mail: bowyerp@bbsrc.ac.uk ized from a variety of sources. Ornithine decarboxylase (ODC) is of particular interest because it catalyses the rate-limiting step in the biosynthesis of polyamines (Tabor and Tabor 1976). There is a dramatic increase in ornithine decarboxylase activity at the onset of cell proliferation. This has been observed in fungi during germination of conidia of Aspergillus nidulans (Stevens et al. 1976), Neurospora crassa (Sikora and McDougall 1978), and cultured mitogenically activated cells (Abrahamsen and Morris 1991). Polyamines bind polyanionic macromolecules such as DNA, RNA, proteins, and phospholipids. The determination of the many and varied functions of polyamines has been made possible by the synthesis of specific inhibitors of polyamine biosynthesis. In general, active growth and cell division are associated with substantial polyamine biosynthesis in plants, animals, and microorganisms (Bagni et al. 1980; Palavan and Galston 1982; Pegg and McCann 1982). Polyamines also have been implicated in plant responses to osmotic stress (Slocum et al. 1984), chilling stress (Guye et al. 1986), and disease (Von Ropenack et al. 1998; Walters 1989), where it is likely that they interact with cell membranes. The synthesis of polyamines in eukaryotes begins with the decarboxylation of ornithine to form putrescine. This reaction is catalyzed by ODC. Higher plants and bacteria can form putrescine in a similar manner. In plants, putrescine also can be produced from agmatine, which itself is formed by the decarboxylation of arginine by the enzyme arginine decarboxylase (Pegg and McCann 1982; Smith 1985; Stevens and Winther 1979; Tabor and Tabor 1985; Walters 1989). Most fungi, including economically important plant pathogens (Rhizoctonia solani, Botrytis cinerea, Fusarium oxysporum f. sp. lycopersici, Phytophthora infestans, and T. yallundae) are prevented from growing by inhibiting ODC with the specific and highly potent inhibitor $\alpha$-difluoromethylornithine (DFMO). The same concentration of DMFO does not inhibit plant growth because plants can synthesize polyamines from arginine. Thus ODC inhibitors have ideal characteristics for use as fungicides on diseased plants. Though DFMO itself is not toxic to plants per se, its toxicity to animals and high cost make it unsuitable for development as a fungicide. Walters (1995) has tested several inhibitors of ODC, S-adenosylmethionine decarboxylase (SAMDC), spermidine synthase, 
or different polyamine analogs for antifungal activity. Most of the compounds showed growth inhibition of a variety of plantpathogenic fungi.

Ruiz-Herrera $(1993 ; 1994)$ has shown that the levels of ODC and polyamine pools increase prior to certain different steps: spore germination, sporulation, and dimorphic transition in several fungal models. An Ustilago maydis ODC null mutant is able to grow at an almost normal rate but is unable to carry out the yeast-to-mycelium transition (Guevara-Olvera et al. 1997). The addition of large exogenous amounts of putrescine or spermidine was necessary to restore the normal dimorphic phenotype of the fungus, demonstrating that high concentrations of polyamines and ODC activity are required in the differentiation of fungi. Whereas in some fungi germination is correlated with increases in ODC activity (Stevens et al. 1976) and the formation of polyamines, the inhibition of polyamine synthesis during germination often has little or no effect on filamentous growth (Brawley and Ferro 1979; Choih et al. 1978). Polyamines are needed, however, for sporulation in Saccharomyces cerevisiae (Cohn et al. 1978) and the optimal development of ascospores in N. crassa (Paulus et al. 1982).

A recent study has shown that ornithine decarboxylase is required for virulence in the ascomycete plant pathogen Stagonospora nodorum (Bailey et al. 2000). Although this finding
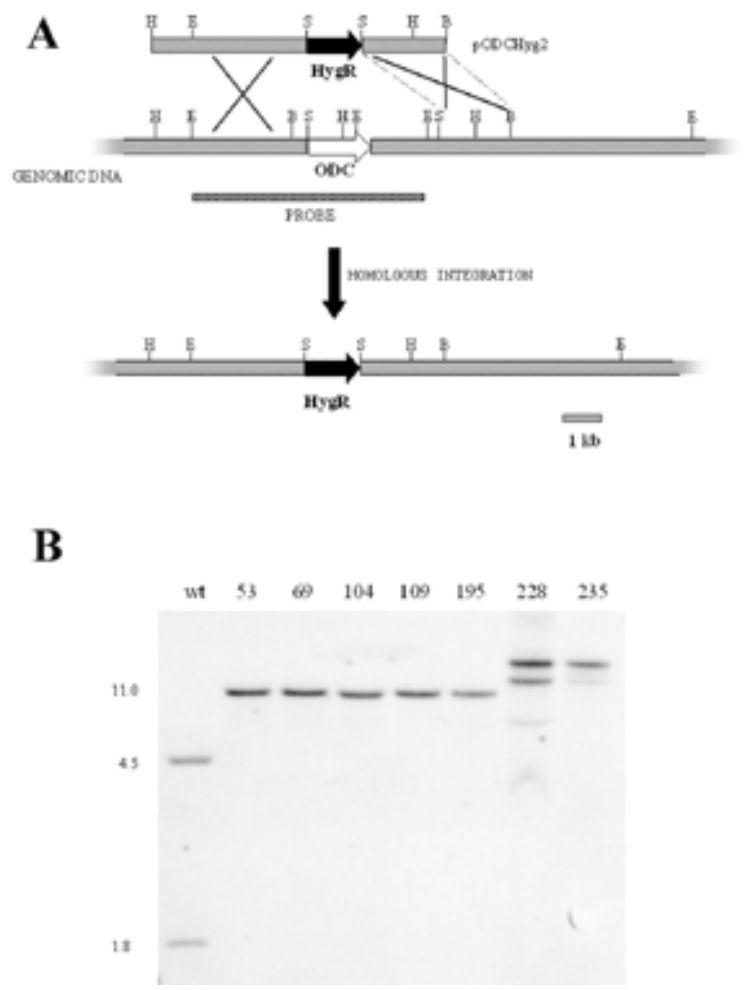

Fig. 1. Gene disruption strategy and Southern blot analysis for ornithine decarboxylase (ODC) gene replacement. A, Strategy for disruption of the Tapesia yallundae ODC1 gene, showing restriction maps of the disruption construct pODCHyg2, ODC1 genomic DNA, and expected gene replacement. The region used to probe Southern blots is indicated by a hatched bar. B = BamHI; E = EcoRV; H = HindIII; S = SalI. B, $5 \mu \mathrm{g}$ of genomic DNA from wild-type W22-433 (lane 1) and transformants 53 (lane 2), 69 (lane 3), 104 (lane 4), 109 (lane 5), 195 (lane 6), 228 (lane 7 ), and 235 (lane 8) were digested with EcoRV, electrophoresed on $0.8 \%$ agarose gel, and transferred to a nylon membrane. Membrane was then hybridized to a probe derived from the $O D C$ lcoding region, as shown. suggests that ODC might be a good fungicide target, it is important to extend this analysis to other pathogenic fungi. $S$. nodorum is a highly necrotrophic pathogen that does not differentiate specialized cells during pathogenesis. In order to test whether an ODC knockout affected the virulence of fungi that rely on the differentiation of complex infection structures for pathogenesis, we examined the importance of polyamine synthesis in virulence and development of a related pathogen of wheat, T. yallundae, which is one of the most serious wheat diseases worldwide (Fitt et al. 1988). To define the role of ODC in polyamine biosynthesis and pathogenicity in this pathogen, gene function was tested genetically by gene disruption. Disruptants showed the essential function of ODC in polyamine metabolism, growth, and infection structure formation, although the disruptants were fully pathogenic.

\section{RESULTS}

\section{Cloning of the $O D C 1$ gene.}

Degenerate oligonucleotides designed against conserved amino acids (IF/YANPCK and NDGVYGS/N) within the ODC proteins of humans (Hickock et al. 1987), yeast (Fonzi and Sypherd 1987), N. crassa (Williams et al. 1992), and Datura spp. (Michael et al. 1996) were used as polymerase chain reaction (PCR) primers to amplify an internal fragment of the $T$. yallundae ODC gene (ODC1). A 609-bp product was obtained with $T$. yallundae DNA as template, cloned into phosphatebuffered saline-SK ${ }^{-}$, and sequenced to confirm its identity. The ODC1 PCR fragment was used to screen a T. yallundae genomic DNA library. Four positive clones were identified after screening 160,000 recombinant phage and purifying their DNA. The DNA of clone 8 was digested with BamHI, and a 5-kb fragment was subcloned into pUC19 (p8BamD19). Sequence analysis (DDBJ/EMBL/GenBank accession no. AF333773) indicated that the entire $O D C 1$ predicted open reading frame (ORF), including $650 \mathrm{bp}$ of upstream sequence, was present. In order to obtain a longer upstream sequence, DNA from clone 10 was digested with HindIII, and a $4.5-\mathrm{kb}$ fragment was subcloned into Litmus38 (p10HindD10). Sequence analysis indicated that part of the $5^{\prime}$ end of the $O D C 1$ ORF and some additional 4-kb upstream sequence were present on this fragment (DDBJ/EMBL/Gen-Bank accession no. AF333773). The predicted amino acid sequence encoded by the ORF of $T$. yallundae genomic ODCl consists of 449 amino acids. The genomic $O D C 1$ sequence contains a 70-bp intron whose size and sequence is conserved between $T$. yallundae, S. nodorum, and N. crassa (Bailey et al. 2000; Williams et al. 1992). The highest degree of amino acid similarity was to the ODC sequence of $N$. crassa (77\%) (Williams et al. 1992) and $S$. nodorum (76\%) (Bailey et al. 2000). The ODCs of T. yallundae and $S$. nodorum were $62 \%$ identical, and the ODCs T. yallundae and N. crassa were $63 \%$ identical, whereas identity to the yeast ODC sequence (Fonzi and Sypherd 1987) was 44\%, and identify to the U. maydis ODC sequence (Guevera-Olvera et al. 1997) was 38\%. Southern analysis of T. yallundae genomic DNA restricted with EcoRI, $P s t$, and BamHI with the $O D C l$ coding sequence as probe revealed only one hybridizing band for each of these enzymes. There were two hybridizing bands of 3.3 and $4.4 \mathrm{~kb}$ when genomic DNA was restricted with HindIII. Sequence analysis showed the presence of an internal HindIII site in the coding 
sequence. This is consistent with the presence of a single ODC gene in the genome of T. yallundae.

\section{ODC1 gene replacement in $T$. yallundae.}

To determine the function of the T. yallundae $O D C 1$ gene, homologous recombination was employed to replace the gene with a selectable marker. Linearized pODCHyg2, which contains a hygromycin resistance cassette flanked by the $5^{\prime}$ and $3^{\prime}$ regions of the $O D C 1$ gene, was used to transform protoplasts of T. yallundae. Primary transformants were selected and purified on potato dextrose agar (PDA) containing $100 \mu \mathrm{g}$ of hygromycin per and $60 \mu \mathrm{M}$ putrescine. Hygromycin-resistant colonies (235) were tested subsequently for growth on medium that did not contain putrescine. Seven auxotrophic colonies, termed Ty $\Delta$ ODC-53, -69, -104, -109, -195, -228, and -235, were identified after the plates had been incubated at $18^{\circ} \mathrm{C}$ for 1 week and, subsequently, at $22^{\circ} \mathrm{C}$ for an additional week. The loss of the $O D C 1$ coding sequence in these mutants was verified by Southern analysis. Figure 1 shows a schematic of the gene disruption protocol and a Southern blot of genomic DNA from the seven mutants and wild-type fungus, restricted with EcoRV and probed with flanking sequences. Two bands of 1.8 and $4.5 \mathrm{~kb}$ were detected in wild-type DNA, whereas one larger band of $11 \mathrm{~kb}$ was seen in the lanes containing DNA from Ty $\Delta$ ODC-53, $-69,-104,-109$, and -195 , which is indicative of the loss of the two internal EcoRV sites by gene disruption. Two of the mutants, Ty $\Delta$ ODC-228 and -235 showed a more complex integration pattern, arising from unknown integration events. The same Southern blot was subsequently stripped and hybridized with a probe comprising the coding region of $O D C 1$. No hybridizing band was detected in the DNA of the seven mutants, which showed that all of them had lost the $O D C 1$ coding sequence, whereas two bands of 1.8 and $4.5 \mathrm{~kb}$ were detected in wild-type DNA (data not shown).

\section{Complementation of Aspergillus nidulans and T. yallundae ODC mutants.}

To show the functionality of the T. yallundae clone and to confirm that the disruption phenotype arose from ODC disruption, the A. nidulans mutant $p u A$ and the T. yallundae ODC1 disruptant Ty $\triangle \mathrm{ODC}-53$ were transformed with the $O D C 1$ gene from $T$. yallundae and the $S$. nodorum ODC gene from a previous study (Bailey et al. 2000). Protoplasts from Ty $\Delta$ ODC-53 were co-transformed with plasmids pAN8-1 (phleomycin resistance cassette) and either pODC or $\mathrm{pXmn} 1$ containing the complete ODC sequence of $T$. yallundae or $S$. nodorum, respectively. The transformants were selected on $500 \mu \mathrm{g}$ of Zeocin per ml (Invitrogen, San Diego, CA, U.S.A.). Three Zeocinresistant transformants, in the case of pODC, and nine transformants for $\mathrm{pXmn} 1$ were identified. These 12 transformants were tested subsequently for complementation of putrescine auxotrophy. One of the pODC transformants, Ty $\Delta$ ODC53/eye, and two of the pXmn1 transformants, Ty $\Delta$ ODC/snod-1 and /snod-2, showed putrescine-independent growth. The pODC transformants contained the $T$. yallundae ODC gene, as assessed by PCR, with primers ODC6 (5'-GTTGAATCTAGTAGCGGAGC-3') and ODC5 (5'-CTTTCTTCGTAGCTGATCTC- $3^{\prime}$ ), which specifically amplified a 1,120-bp fragment of the T. yallundae ODC coding sequence. This diagnostic band was in PCR reactions with DNA isolated from wild-type T. yallundae and from Ty $\Delta$ ODC53eye but not from
Ty $\Delta$ ODC53 (Fig. 2A). Primers ODCsnod-1 and ODCsnod-2 (5'-GTGTTGAAAATCATGGCGCC-3' and 5'-TGCCCAGAGTAGCATCGGCG-3', respectively) specifically amplified a 932-bp fragment of the $S$. nodorum ODC coding sequence from DNA isolated from Ty $\Delta$ ODC53/snod-2 but not from DNA isolated from Ty $\Delta$ ODC53 (Fig. 2B). The $S$. nodorum ODC gene is thus able to complement the T. yallundae ODC mutant phenotype. The A. nidulans ODC mutant ( $p u \mathrm{~A} 2-b i \mathrm{~A} 1)$ (Sneath 1955) is auxotrophic for putrescine and biotin. Protoplasts from this mutant were isolated and transformed with pODC. The recovered transformants, termed A. nidulans/eye1-8, were selected directly for complementation of putrescine auxotrophy, demonstrating that the $T$. yallundae $O D C 1$ gene was capable of complementing the puA2 mutation. DNA was isolated from A. nidulans/eye 2 and /eye 5 and the insertion of the pODC into the fungal genome verified by PCR (Fig. 2C). Primers TYODC18 (5'-GTATTG-ATTCTGGTAGTACG-3') and TYODC3 (5'-ATCAGTTTG-AATCGGTAATC-3') specifically amplified the predicted 650-bp fragment from wildtype $T$. yallundae and $A$. nidulans/eye 2 and /eye 5 but not from the DNA isolated from the A. nidulans puA2-biA1 mutant. These transformants were tested for their ability to germinate and sporulate in the absence of exogenous putrescine. All showed normal growth and differentiation.

\section{ODC enzyme activity in wild-type and mutant fungus.}

ODC enzyme activity was determined in wild-type and $\mathrm{ODC}^{-}$T. yallundae Ty $\Delta \mathrm{ODC}-53$. Because ODC activity was difficult to detect in mycelia, we determined activity in germinating spores where activity was expected to be high. Spores were harvested from TWA plates and washed with sterile distilled water. The spores were suspended in $100 \mathrm{ml}$ of CzapekDox liquid media at $2 \times 10^{7}$ conidia per ml. It was observed that most of the $T$. yallundae conidia had already formed a germ tube when collected from TWA plates. Therefore, the conidia were conditioned only for $2 \mathrm{~h}$ in the Czapek-Dox liquid media in an orbital shaker at $220 \mathrm{rpm}$ at $20^{\circ} \mathrm{C}$. The conidia were harvested onto $47-\mathrm{mm}$ nitrocellulose filters $(0.45-\mu \mathrm{m}$ pore size) and used in the ODC activity assay, as described. ODC activity for wild-type T. yallundae is $321.00 \pm 34.64$ $\mathrm{pMol} \mathrm{CO}_{2}$ per $\mathrm{mg}$ of protein, whereas ODC activity in

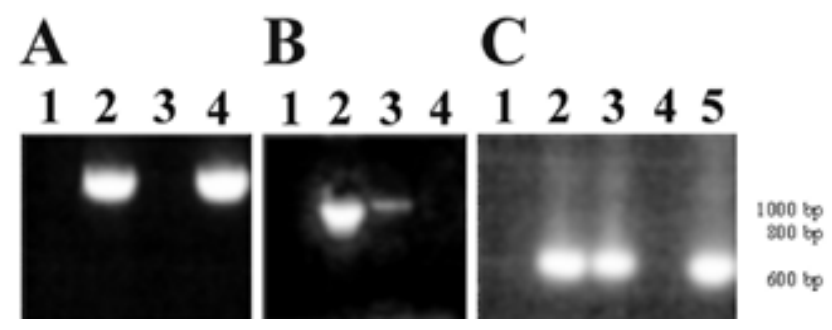

Fig. 2. Complementation analysis of ornithine decarboxylase (ODC) genes. A, Polymerase chain reaction (PCR) from Tapesia yallundae and Ty $\triangle$ ODC53 transformed with pODC with primers ODC6 and ODC5. $1=$ control without DNA; 2 = Ty $\Delta$ ODC53-eye DNA; 3 = Ty $\Delta$ ODC53 DNA; 4 = wild-type $T$. yallundae DNA. B, PCR from Ty $\Delta$ ODC53 transformed with pXmn1 with primers ODCsnod 1 and ODCsnod2. $1=$ control without DNA; $2=$ DNA from Ty $\Delta$ ODC53/snod $1 ; 3=$ DNA from Ty $\Delta$ ODC53/snod2; 4 = DNA from Ty $\Delta$ ODC53. C, PCR from Aspergil lus nidulans puA2 biA1transformed with pODC with primers TYODC18 and TYODC3. $1=$ control without DNA; $2=A$. nidulans-eye2 DNA; $3=$ A. nidulans-eye 5 DNA; $4=A$. nidulans puA2 biA1 mutant DNA; $5=T$. yallundae wild-type DNA. 
Ty $\Delta$ ODC-53 is $44.48 \pm 11.87 \mathrm{pMol}$ of $\mathrm{CO}_{2}$ per mg of protein. Peak wild-type activity is approximately 25 -fold lower than peak activity in A. nidulans (biA1) (Stevens et al. 1976). Stevens et al. (1976) and Bailey et al. (2000), however, showed that ODC activity peaked approximately 8 to $10 \mathrm{~h}$ after the start of germination. The germination of $A$. nidulans and $S$. nodorum conidia was relatively synchronous. It was found that $T$. yallundae conidia harvested from TWA plates showed a range of different germination stages. This asynchronous germination could explain the lower ODC activity observed.
A

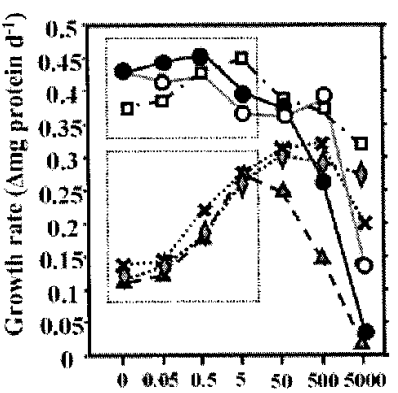

[Polyamine] $\mathrm{HM}$

$\mathrm{C}$

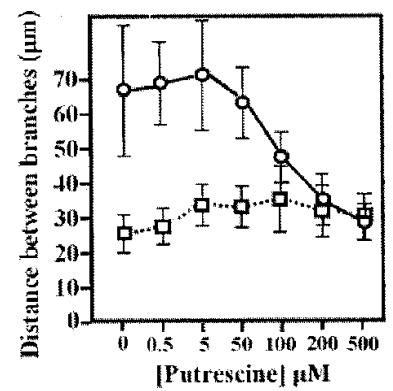

$\mathrm{B}$

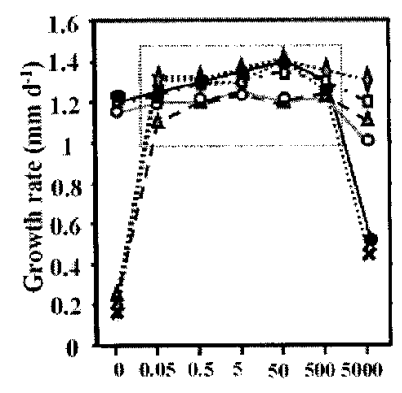

[Polysumine] $\mu \mathrm{M}$

$\mathrm{D}$

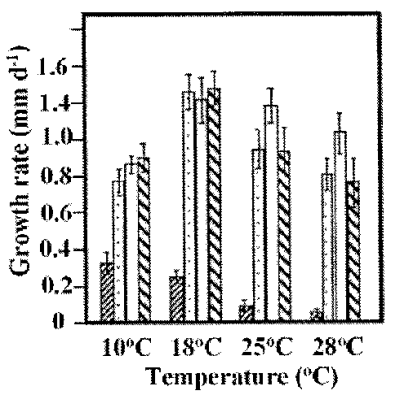

Fig. 3. Growth phenotype of wild-type and $O D C 1^{-}$fungi in the presence or absence of polyamines. A, Rate of increase of hyphal biomass of Tapesia yallundae wild-type and $O D C 1^{-}$mutant Ty $\triangle \mathrm{ODC} 53$ at $18^{\circ} \mathrm{C}$ on minimal medium (MM) containing various concentrations of putrescine, spermidine, or spermine. B, Rate of hyphal extension of $T$. yallundae wild-type and $O D C 1^{-}$mutant at $18^{\circ} \mathrm{C}$ on $\mathrm{MM}$ agar containing various concentrations of putrescine, spermidine or spermine. Shaded circle = wild-type during growth on spermine; open circle = wild-type during growth on spermidine; open square $=$ wild-type during growth on putrescine; $\mathrm{X}=\mathrm{Ty} \Delta \mathrm{ODC} 53$ during growth on spermine; open triangle = Ty $\triangle$ ODC53 during growth on spermidine; and open diamond = Ty $\Delta$ ODC53 during growth on putrescine. C, Frequency of hyphal branching for wild-type (open square) and $O D C 1^{-}$mutant Ty $\triangle$ ODC53 (open circle) at various putrescine concentrations. D, Temperature-sensitive phenotype of $\mathrm{ODC}^{-}$strains. Radial growth rates were measured for wild-type and mutant $T$. yallundae on MM agar in the presence or absence of $60 \mu \mathrm{M}$ putrescine at various temperatures. Growth rates were measured for 10 separate experiments then subjected to statistical analysis. Bars with lines sloping to the left $=$ Ty $\Delta$ ODC53 without supplementary putrescine; bars with dots $=$ Ty $\Delta$ ODC $53+60 \mu \mathrm{M}$ putrescine; white bars = wild-type without supplementary putrescine; bars with lines sloping to the right $=$ wild-type $+60 \mu \mathrm{M}$ putrescine. Error bars have been omitted from $\mathbf{A}$ and $\mathbf{B}$ for clarity. Dashed boxes enclose data points that are not significantly different from each other but show significant difference to other similarly enclosed boxes.

\section{Growth phenotypes of $\mathrm{ODC1}^{-} \mathrm{T}$. yallundae.}

To test the ability of different polyamines to restore growth of the $\mathrm{ODCl}^{-}$mutant, strains were grown on minimal medium containing a range of polyamine concentrations. As measurement of hyphal growth rate on agar medium is not likely to reflect the true increase in fungal biomass, we also measured the rate of increase of hyphal biomass during growth in liquid medium. Growth was restored to near wild-type levels in liquid medium with the addition of $50 \mu \mathrm{M}$ putrescine, spermidine, or spermine (Fig. 3A), although higher concentrations of spermine decreased growth. The $O D C 1^{-}$mutant was restored to wild-type growth rate on minimal medium (MM) agar with the addition of $0.5 \mu \mathrm{M}$ putrescine, spermine, or spermidine (Fig. 3B). The discrepancy between these results may arise from the fact that growth rate on solid media is measured as the rate of colony expansion and growth in liquid medium is measured as the rate of increase in biomass.

An alternative explanation may be that agar contains trace amounts of polyamines. If this were the case, however, increased levels of mutant growth would be expected on solid media. Visual observation of $O D C 1^{-}$colonies grown on 0.5 to $50 \mu \mathrm{M}$ polyamine show that, although colony expansion is normal, hyphal growth is sparse. To reconcile these differences, we tested whether differences in hyphal growth rate and increase in biomass might arise from decreased hyphal branching at low polyamine concentrations. Wild-type W22433 and Ty $\Delta$ ODC53 were inoculated into the center of $9-\mathrm{cm}$ petri dishes containing various concentrations of polyamines, and hyphal branch distance was measured on a Axiovert 125 microscope (Carl Zeiss, Thornwood, NY, U.S.A.) with a calibrated reticule for comparison. Hyphal branch distance in wild-type T. yallundae is independent of exogenous polyamine concentration but the $O D C 1^{-}$mutant produces hyphal branches less frequently at low polyamine levels (Fig. 3C). This difference may reflect a role for polyamines in the positioning or initiation of hyphal branching in fungi.

The $O D C 1$ null mutants behaved as polyamine auxotrophs when grown on minimal media at $28^{\circ} \mathrm{C}$. Significant mycelial growth was observed at lower temperatures (Fig. 3D), although the hyphae were thin, less melanized, and growing sparsely. This suggests a requirement for polyamines in stabilizing cellular components at higher temperatures. It also was noted that the addition of $60 \mu \mathrm{M}$ putrescine to the medium at 25 and $28^{\circ} \mathrm{C}$ also caused a small but significant reduction in growth relative to unamended media.

\section{Differentiation of infection structures by knockout mutants.}

T. yallundae differentiates specialized multicellular infection structures, which are essential for its pathogenicity. They form by cell swelling that arises from hyphae by repeated apical branching and septation. These structures are induced in vitro by contact with solid surfaces such as the base of petri dishes or inert membranes (Deacon 1973). Infection plaque formation was induced in vitro under a hydrophobic polytetrafluorethylene membrane in the presence and absence of exogenous putrescine at $10^{\circ} \mathrm{C}$. A plaque formation assay was set up with Ty $\Delta$ ODC53, Ty $\Delta$ ODC53/snod2, and Ty $\Delta$ ODC53/eye to investigate the requirement of polyamines and $O D C 1$ in the formation of these structures. Plaque formation was studied at $10^{\circ} \mathrm{C}$ to allow hyphal growth of unsupplemented $O D C 1$ 
knockout strains. Ty $\Delta$ ODC53, Ty $\Delta$ ODC53/eye, and W22-433 conidia were harvested from unsupplemented TWA plates and plated onto TWA plates in the absence or presence of $60 \mu \mathrm{M}$ putrescine. The inoculum was covered by a layer of sterile Biofolie membrane (Heraeus, Hanau, Germany). When incubated at $10^{\circ} \mathrm{C}$ under constant white light, the conidia germinated and started to form infection plaques under the membrane within 4 to 10 days. The in vitro formation of infection plaques was assessed after 7 days. Wild-type W22-433, Ty $\Delta$ ODC53/eye, and Ty $\Delta$ ODC53/snod 2 were able to form infection plaques under inductive conditions in the absence of polyamines. Ty $\Delta$ ODC53 conidia germinated and were able to form hyphae and grow as mycelia at the permissive temperature of $10^{\circ} \mathrm{C}$ but were unable to produce infection plaques under inductive conditions in the absence of putrescine. Supplementation of the medium with $60 \mu \mathrm{M}$ putrescine restored the ability of Ty $\Delta$ ODC53 to form highly melanized infection structures, identical to wild type infection plaques, under inductive conditions (Fig. 4).

\section{Pathogenicity of $O D C 1$ knockout strains.}

Conidia from the Ty $\Delta$ ODC53 and wild-type W22-433 were inoculated onto 2-week-old wheat seedlings. Symptoms were visible on the susceptible wheat cultivar Avalon at 6 weeks postinoculation. Distinct "eyespot" lesions, which penetrated several leaf sheaths, were observed after 8 weeks. Ty $\Delta$ ODC53 showed no apparent delay in symptom appearance or virulence compared with the wild type. Quantitative PCR was used to provide a measure of fungal biomass during infection. Infected stem bases were analyzed by competitive PCR. Fifty plants for each treatment were divided into pools of five plants and freeze dried. The dried material was sent to P. Nicholson at the John Innes Centre (Norwich, U.K.) where the DNA extraction and the quantitative competitive PCR were performed (Nicholson et al. 1997). The PCR was repeated twice, and each sample was replicated 10 times. The amounts of wildtype and Ty $\triangle$ ODC53 DNA present in the stem-base lesions were $0.034 \pm 0.006$ and $0.0295 \pm 0.0065 \mu \mathrm{g}$ of sample per $\mu \mathrm{l}$, respectively. These values are not significantly different when compared with a Turkey's $t$ test at $1 \%$ significance level (giving a $p$ value of 0.771 ). Visual symptoms on these plants also were scored according to Scott and Hollins (1974). The disease index for the plants used in the quantitative DNA assessment is 76.9 for wild type and 57.8 for Ty $\Delta$ ODC53. This suggests that there is a small but significant decrease in symptom expression for Ty $\triangle$ ODC53 compared with wild type using a Student's $t$ test $(p=<0.01)$. In a repeat experiment, however, disease indexes were 65.3 for wild type and 59.2 for Ty $\Delta$ ODC53, which is not significant when compared as a Student's $t$ test at $1 \%$ significance level $(p=0.143)$. This suggests that scoring disease by visual assessment may be subject to variability. The mean disease index and DNA levels, however, were lower for $O D C 1$ knockout mutants on all occasions tested. This may suggest a slight reduction in virulence, which might become statistically significant in a larger experiment.

\section{DISCUSSION}

Degenerate nested primers to sequences conserved in eukaryotic ODCs were used to clone the ODC gene of $T$. yallundae with a PCR-based approach. The 605-bp PCR fragment was cloned, and its sequence showed characteristics typical of previously cloned ODCs. This fragment was then used to screen a genomic library made of T. yallundae DNA. Several positive clones were obtained, and a 5-kb hybridizing BamHI fragment from one of the fragments was subcloned into pUC19. Sequence analysis revealed that it contained the whole $O D C 1 \mathrm{ORF}$, and approximately $600 \mathrm{bp}$ of upstream sequence. The deduced amino acid sequence shows high homology to the $N$. crassa ODC gene. Both have a 70-bp intron conserved at the same position in the coding sequence. A plasmid containing the complete $T$. yallundae $O D C 1$ gene was used to successfully complement an $A$. nidulans putrescine auxotroph by restoring vegetative growth and asexual sporulation.

Putrescine requiring mutants of $T$. yallundae were made by transformation-mediated targeted gene replacement of the $O D C 1$ gene. $O D C 1$ knockout mutants exhibited temperature-dependent growth with higher temperatures, restricting hyphal elongation. This observation suggests some role of polyamines in stabilization of cell components. The $O D C l$ disruptants grow at a similar rate to the wild type when supplemented with sufficient putrescine. Biomass was reduced in the mutant strains, however, when exogenous polyamine levels were below $50 \mu \mathrm{M}$. The discrepancy between biomass and hyphal growth rate seemed to result from decreased hyphal branching in the $O D C 1$ knockout strains. $O D C 1$ knockout strains were unable to form infection structures in the absence of exogenous polyamines, suggesting a role for polyamines in differentiation and hyphal branching in this organism.

Pathogenicity assays of the mutant strains with use of spore inoculum showed no reduction in virulence compared with the wild type. $O D C 1$ knockout mutants also developed the same biomass as wild type during infection. This suggests that the

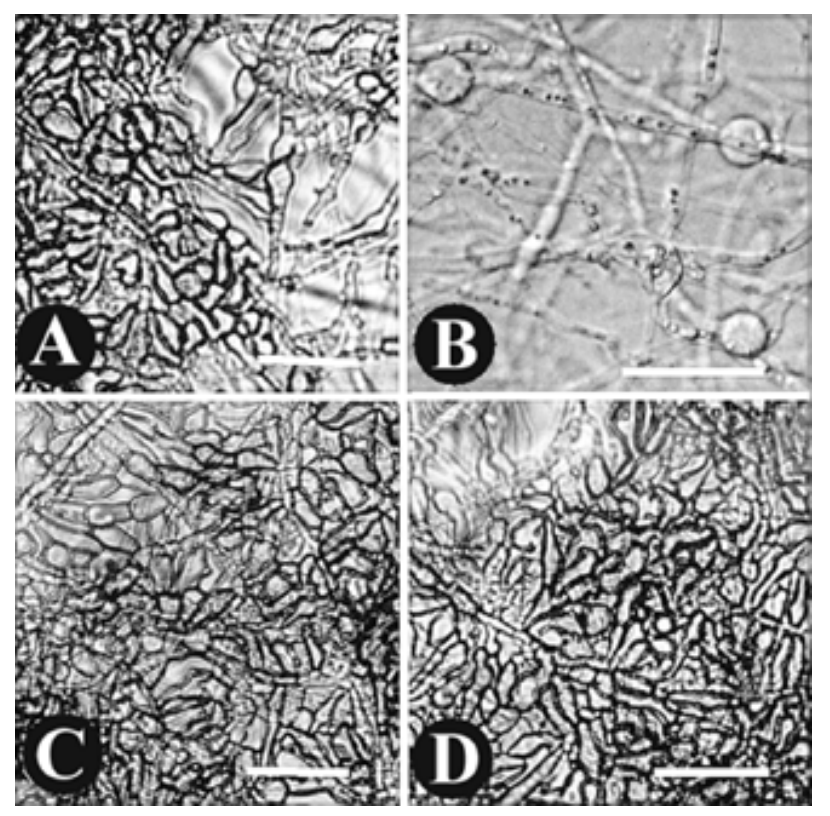

Fig. 4. Infection structure formation of mutant and wild-type strains in the presence and absence of putrescine. Tapesia yallundae hyphae were grown on agar plates under inductive conditions at $10^{\circ} \mathrm{C}$, as described. Micrographs show infection structure formation 7 days after induction. Bars $=20 \mu \mathrm{m}$. A, Wild-type T. yallundae infection structures on unsupplemented minimal medium (MM). B, Ty $\Delta$ ODC53 hyphae on unsupplemented MM. C, Wild-type T. yallundae infection structures on MM + $60 \mu \mathrm{M}$ putrescine. D, Ty $\Delta$ ODC53 infection structures on $\mathrm{MM}+60 \mu \mathrm{M}$ putrescine. 
fungus can access up to $\geq 50 \mu \mathrm{M}$ polyamines during infection. Visual inspection of lesions confirmed that all infection structures were formed normally by wild-type and knockout mutants. Analysis of symptom expression did not provide consistent results with repeats of the assay, giving statistically different results. In all cases, there was a minor reduction in lesion formation, which may arise from differences in hyphal morphology at low polyamine concentrations. This result is unexpected, given that the mutants were auxotrophic for polyamines and were unable to form infection structures in vitro under inductive conditions. The most plausible explanation for these findings is that the fungus is able to effectively scavenge for sufficient polyamines to support growth and differentiation from the plant during infection. It is intriguing to note that ODC gene disruption in the wheat pathogen S. (Septoria) nodorum causes major reduction in virulence toward wheat (Bailey et al. 2000). There may be several explanations for the difference in virulence caused by ODC disruption in these two pathogens. First, they may display different abilities to take up polyamines from the host plant. Second, the pathogens may have different requirements for polyamines, resulting from their different lifestyles, in that $S$. nodorum elaborates no infection structures and grows rapidly through plant tissue, whereas $T$. yallundae elaborates several different types of infection structure and ramifies slowly through plant tissue. Finally, the two pathogens attack different plant tissues, leaves, and stem bases, which may contain different concentrations of free polyamine. The observation that the disruption of homologous genes from different fungi can have widely different effects on pathogenicity and phenotype also must engender caution when extrapolating results obtained in one fungal pathogen to other pathogens. It would be interesting to see whether these strains are more sensitive to toxic polyamine analogs (Havis et al. 1994a: Havis et al. 1994b, Mackintosh and Walters 1997) than the wild type because they must utilize a polyamine uptake system to supply their requirement. It is noteworthy that a number of plant defense compounds are polyamine conjugates. Given the need for the uptake of exogenous polyamines, it is possible that the mutants would be more sensitive to such compounds.

\section{MATERIALS AND METHODS}

\section{Strains and growth.}

T. yallundae strain $\mathrm{W}-22-433$ was used throughout the study. Cultures were maintained routinely as plug inocula from master plates or frozen mycelial stocks on $1.5 \%$ PDA (Oxoid, Basingstoke, U.K.). Plug inocula were put onto $1.5 \%$ tap water agar (TWA) for the production of conidia. ODC1 mutants were grown on Czapek-Dox solid media (Oxoid) supplemented with trace elements $\left(46 \mathrm{mg}\right.$ of $\mathrm{MnSO}_{4} 7 \mathrm{H}_{2} \mathrm{O}, 65.9 \mathrm{mg}$ of $\mathrm{ZnSO}_{4} 7 \mathrm{H}_{2} \mathrm{O}, 59 \mathrm{mg}$ of $\mathrm{CuSO}_{4} 5 \mathrm{H}_{2} \mathrm{O}, 75 \mathrm{mg}$ of $\mathrm{FeSO}_{4}$ $7 \mathrm{H}_{2} \mathrm{O}$, and $37.8 \mathrm{mg}$ of $\mathrm{Na}_{2} \mathrm{MoO}_{4} 2 \mathrm{H}_{2} \mathrm{O}$ per liter), $59 \mu \mathrm{M}$ thiamine, $81 \mathrm{nM}$ biotin, $7.2 \mu \mathrm{M}$ p-amino-benzoic acid (PABA), and $60 \mu \mathrm{M}$ putrescine. For mycelial suspensions, plugs were inoculated into Czapek-Dox-V8 media and grown with shaking for 2 days at $18^{\circ} \mathrm{C}$ and $250 \mathrm{rpm}$. The grown mycelium was subsequently macerated and reinoculated into fresh CzapekDox-V8 media. Mycelial suspensions used for protoplast preparation were treated with $2.5 \mathrm{~cm}^{2}$ of fungal plug and inoculated into $100 \mathrm{ml}$ of previously centrifuged Czapek-Dox-
V8 in a 250-ml flask. The mycelial plug was macerated with a polytron in a $250-\mathrm{ml}$ flask and incubated for 3 days with shaking at $250 \mathrm{rpm}$ and $18^{\circ} \mathrm{C}$. The fungal suspension was again macerated with the polytron, subcultured into Czapek-Dox$0.8 \%$ yeast extract, and grown for another $16 \mathrm{~h}$ at $18^{\circ} \mathrm{C}$ and $250 \mathrm{rpm}$. A. nidulans strain G0171 (puA2-biA1) was grown on complete media (20.0 g of Difco malt extract, $1.0 \mathrm{~g}$ of Bacto Peptone, $20.0 \mathrm{~g}$ of glucose, $20.0 \mathrm{~g}$ of Bacto agar, and appropriate supplements in $1,000 \mathrm{ml}$ of $\mathrm{H}_{2} \mathrm{O}$ ).

\section{Pathogenicity tests.}

Pathogenicity tests were carried out in a growth chamber. Winter wheat (cv. Avalon), which is susceptible to eyespot, was grown in M3 compost (Levington Horticulture, Ipswich, U.K.) in $9-\mathrm{cm}$ diameter pots. Ten seeds were sown into each pot and incubated for 10 days at $16^{\circ} \mathrm{C}$ under $12 \mathrm{~h}$ of white light. Ten days after sowing, seedlings were inoculated with $5 \times 10^{5}$ conidia harvested from TWA plates with $0.9 \% \mathrm{NaCl}-$ $0.5 \%$ Tween 40 solution. The relative humidity in the growth chamber was $95 \%$, temperature was kept at $12^{\circ} \mathrm{C}$, and day length was $12 \mathrm{~h}$. The severity of stem lesions was assessed with the method used by Scott and Hollins (1974) on a scale of 0 to 3. A score of 0 indicates no visible stem symptoms, and a score of 3 indicates that the stem was girdled completely by lesions, resulting in the softening of stem tissue. Quantification of fungal biomass in infected stem tissue by quantitative PCR with the method of Nicholson et al. (1997) was used as an additional measure of infection.

\section{Plasmids.}

The plasmids used in the transformation of $T$. yallundae were pST28, which was constructed by ligating a 1.4-kb HpaI fragment from pCB1004 (Carroll et al 1994) containing the hygromycin resistance from Escherichia coli under control of the $\operatorname{Trp} C$ promoter from $A$. nidulans into pLitmus28 (New England Biolabs, Beverly, MA, U.S.A.). Plasmid pAN8-1 contains the phleomycin gene from Streptococcus hindustanus flanked by the highly expressed $A$. nidulans gpd gene and the terminator region of the $A$. nidulans $\operatorname{trp} C$ gene (Mattern and Punt 1988). Plasmid DNA was isolated by a modification of the alkaline lysis method (Birnboim and Doly 1979) and the use of miniprep columns (Qiagen, Crawley, U.K.). The knockout plasmid pODCHyg2 was constructed as follows. The genomic $O D C 1$ clone p8BamD19, consisting of a 6-kb BamHI fragment containing the complete $O D C l \mathrm{ORF}$ in pBluescriptII $\mathrm{KS}$, was cut with the restriction enzyme SpeI, and a 3-kb fragment was removed. The resulting $3^{\prime}$ protruding ends were "filled in" with the Klenow fragment of E. coli DNA polymerase. A 1.4-kb HpaI fragment from plasmid pST38 containing the hygromycin resistance gene from $E$. coli under control of the $\operatorname{trp} C$ promoter from A. nidulans was then ligated into the SpeI cut and blunt-ended vector $\mathrm{p} 8 \mathrm{BamD} 19$, creating plasmid pODCHyg. This plasmid contained flanking sequences 660-bp upstream and 1.9-kb downstream of the ODC1 ORF. The resulting plasmid contained the hygromycin resistance cassette and $35 \mathrm{bp}$ of the $O D C 1$ coding sequence. An 8-kb Bam HI fragment from pODCHyg containing the hygromycin resistance cassette and the flanking sequences of the $O D C 1$ gene was ligated into BamHI-restricted p10HindD10, consisting of a 4.5-kb HindIII genomic region comprising the $5^{\prime}$ section of the $O D C l$ gene and upstream sequences, removing a 
1.2-kb BamHI fragment from $\mathrm{p} 10 \mathrm{HindD} 10$ and creating pODCHyg2.

\section{DNA isolation and Southern blotting.}

DNA was purified by a modification of the method used by Specht et al. (1982). Liquid cultures were collected on Miracloth in a funnel and washed with TSE $(150 \mathrm{mM} \mathrm{NaCl} ; 100 \mathrm{mM}$ EDTA; and $50 \mathrm{mM}$ Tris $\mathrm{HCl}, \mathrm{pH} 8.0$ ). The washed mycelia subsequently were freeze dried, and $1 \mathrm{~g}$ of dry-weight mycelia was ground to a fine powder and transferred to a $250-\mathrm{ml}$ conical flask. Twenty-five milliliters of extraction buffer (TSE + $2 \%$ sodium dodecyl sulfate [SDS]) and 0.2 (vol/vol) of toluene was added. The flask was shaken very slowly on a rotary shaker for 3 days. The DNA was separated from the toluene by spinning at $15,000 \times g$ for $15 \mathrm{~min}$ in a SS34 rotor. The DNA was concentrated in the interphase between the water and toluene phase. The DNA was removed and spun again to remove the toluene, 0.25 volume of $7.5 \mathrm{M} \mathrm{NH}_{4} \mathrm{Ac}$ was added, and the polysaccharides were precipitated overnight at $4{ }^{\circ} \mathrm{C}$. The polysaccharides were then pelleted at $39,000 \times g$ for $30 \mathrm{~min}$ in a SS34 rotor. The DNA was precipitated with 0.7 volume of isopropanol. The precipitate was fished out with a sealed-off Pasteur pipette and resuspended in $750 \mu \mathrm{l}$ Tris-EDTA (TE; $10 \mathrm{mM}$ Tris-HCl, $\mathrm{pH} 7.5$; and $1 \mathrm{mM}$ EDTA) and $50 \mu \mathrm{g}$ of RNase per $\mathrm{ml}$. The RNase digestion was performed at $37^{\circ} \mathrm{C}$ for $30 \mathrm{~min}$. Proteinase $\mathrm{K}$ was added to $100 \mu \mathrm{g}$ of the solution per $\mathrm{ml}$ and left to incubate for another $2 \mathrm{~h}$ at $37^{\circ} \mathrm{C}$. The DNA solution was extracted with phenol- $\mathrm{CHCl}_{3}$. The DNA was precipitated once more and resuspended in TE. For Southern analysis, $2 \mu \mathrm{g}$ of genomic fungal DNA was digested with different restriction enzymes overnight at the appropriate temperature. The DNA was separated on $0.8 \%$ agarose gel and standard techniques (Sambrook et al. 1989) were employed to treat and blot the DNA onto a nylon membrane (Amersham Pharmacia Biotech, Uppsala, Sweden). Prehybridization and hybridization solutions were $5 \times$ Denhardt's (2\% gelatin, 2\% Ficoll-400, 2\% polyvinylpyrrolidone [PVP]-360, and 10\% SDS), $100 \mu \mathrm{g}$ of denatured calf thymus DNA per $\mathrm{ml}, 0.2 \%$ SDS, and $1 \times \mathrm{HSB}(3 \mathrm{M}$ $\mathrm{NaCl}$; $0.1 \mathrm{M}$ piperazine- $N, N^{\prime}$-bis[21-ethanesulfonic acid]; and $20 \mathrm{mM}$ EDTA, pH 6.8). Hybridization was performed overnight at $65^{\circ} \mathrm{C}$. All washes were performed twice for $30 \mathrm{~min}$ at high stringency: $0.1 \times \mathrm{SSC}(1 \times \mathrm{SSC}$ is $0.15 \mathrm{M} \mathrm{NaCl}$ plus $0.015 \mathrm{M}$ sodium citrate) and $0.5 \% \mathrm{SDS}$ at $65^{\circ} \mathrm{C}$.

\section{PCR of ornithine decarboxylase from $T$. yallundae.}

For PCR, $100 \mathrm{ng}$ of genomic DNA of T. yallundae was used in a "hot-start" PCR reaction. The amplification conditions were as follows: $94^{\circ} \mathrm{C}$ for $5 \mathrm{~min}$ and $75^{\circ} \mathrm{C}$ for $5 \mathrm{~min}$, then 35 cycles of $94^{\circ} \mathrm{C}$ for $1 \mathrm{~min}, 52^{\circ} \mathrm{C}$ for $2 \mathrm{~min}$, and $72^{\circ} \mathrm{C}$ for $3 \mathrm{~min}$. The degenerate primers were used at a final concentration of $2.5 \mu \mathrm{M}$. One-hundredth of the first-round product was used in the second-round PCR with the inner pair of nested primers under identical amplification conditions. The outer pair of primers were the $5^{\prime}$ primer $\left[5^{\prime}-\mathrm{CCNTT} / \mathrm{C}\right) \mathrm{TA}(\mathrm{T} / \mathrm{C}) \mathrm{GCNGTN}$ $\left.\mathrm{AA}(\mathrm{A} / \mathrm{G}) \mathrm{TG}(\mathrm{T} / \mathrm{C}) \mathrm{AA}-3^{\prime}\right]$, representing the amino acid sequence PFYAVKCN, and the $3^{\prime}$ primer $\left[5^{\prime}-\mathrm{CC}(\mathrm{A} / \mathrm{G}) \mathrm{TC}(\mathrm{A} / \mathrm{G})-\right.$ CANGTNGGNCCCCA-3'], representing the sequence WGPTCDG. The second-round internal pair of primers were the $5^{\prime}$ primer [5'-TNATNT(T/A)(T/C)GCNAA(T/C)CCNTG-3'], representing the amino acid sequence $\mathrm{I}(\mathrm{F} / \mathrm{Y}) \mathrm{ANPC}$, and the $3^{\prime}$ primer [5'-TNCC(A/G)TANACNCCA(A/G)TC(A/G)TT-3'], representing the sequence $\mathrm{NDGVYG}(\mathrm{S} / \mathrm{N})$. The products of several PCRs were pooled and size fractionated on a $1.5 \%$ (wt/vol) agarose gel. After the second round of PCR, only one distinct band of the right size was visible after ethidium bromide staining, and DNA from that band was isolated and cloned as a blunt-ended fragment into the EcoRV site of the vector pBluescript II SK+ (Stratagene, Cambridge, U.K.). The identity of the cloned fragment was determined by sequencing the PCR product.

\section{Genomic library and screening.}

A T. yallundae genomic library was prepared in LambdaGEM12 (Promega, Southampton, U.K.). T. yallundae genomic DNA was partially restricted with Sau3A. The Sau3A sites were partially filled with Klenow polymerase and ligated into partial filled XhoI half-site arms of LambdaGEM12. The ligation reaction was packaged with the GigapackIII Gold Kit according to the manufacturer's protocol (Stratagene), and phage titers were determined in the bacterial host strain LE392. The ODC1 PCR product was radioactively labeled with the High Prime Kit (Roche Diagnostics, Lewes, U.K.) and used to probe the genomic library. The positive plaques were purified by an additional three rounds of screening.

\section{Sequencing.}

All sequencing reactions were performed on doublestranded plasmid DNA with a ABI PRISM Dye Terminator Cycle Sequencing Ready Reaction Kit (Perkin-Elmer, Beaconsfield, U.K.). The sequence of both strands of the genomic $O D C 1$ clone was determined by a combination of oligonucleotide primer walking and subcloning into pUC18. Sequence determination was carried out with a Perkin-Elmer ABI377 automated sequencer and analyzed with the Genetics Computer Group's software package, version 8 (Madison, WI, U.S.A.).

\section{Transformation of T. yallundae.}

Mycelia were grown, as outlined previously, collected on sterile Miracloth (Calbiochem, Beeston, U.K.) by vacuum filtration, and washed with sterile water. A sterile spatula and forceps was used to place the mycelial pad in a sterile tube and weighed before resuspension in $10 \mathrm{ml}$ per $\mathrm{g}$ of $1 \mathrm{M}$ sorbitol. After two washes in $1 \mathrm{M}$ sorbitol, $4 \mathrm{mg}$ per $\mathrm{ml}$ of freshly prepared Novozyme 234 (InterSpex Products, Foster City, CA, U.S.A.) in $1 \mathrm{M}$ sorbitol was added. Mycelia were digested by shaking gently at room temperature for $2 \mathrm{~h}$. The digest was checked regularly for the release of protoplasts. The digested mycelia was filtered through four layers of sterile Miracloth and washed with $1 \mathrm{M}$ sorbitol. Protoplasts were pelleted at $2,665 \times g$ in a tabletop centrifuge at $15^{\circ} \mathrm{C}$. The pellet was resuspended in $1 \mathrm{M}$ sorbitol. This wash was repeated twice. Protoplasts were resuspended at a concentration of $5 \times$ $10^{7}$ protoplasts per $\mathrm{ml}$. Protoplast solution $(200 \mu \mathrm{l})$ was mixed with $5 \mu \mathrm{g}$ of linearized plasmid DNA, then incubated for 15 min at room temperature. One milliliter of polyethylene glycol (PEG) solution (25 mM Tris $\mathrm{HCl}, \mathrm{pH} 7.5 ; 25 \mathrm{mM} \mathrm{CaCl}_{2}$; and $66 \%$ PEG 8000) was added slowly over $30 \mathrm{~min}$. Three milliliters of liquid TB3 $(0.3 \%$ yeast extract, $0.3 \%$ Casamino Acids, and $20 \%$ sucrose) was added and mixed. TB3 containing $2 \%$ agarose was melted and kept at $50^{\circ} \mathrm{C}$, then added to and mixed with the protoplast suspension, which was poured into 
9-cm petri dishes. The plates were incubated overnight at $18^{\circ} \mathrm{C}$ and, the next day, overlaid with $1.5 \%$ PDA $+100 \mu \mathrm{g}$ of Hygromycin B per ml, in the case of pST28, or $500 \mu \mathrm{g}$ of Zeocin per $\mathrm{ml}$, for pAN8-1. The plates were incubated at $18^{\circ} \mathrm{C}$ in the dark until the first microcolonies were visible. The microcolonies were transferred weekly to fresh selective media.

\section{Transformation of $A$. nidulans.}

A. nidulans was transformed, essentially as described by de Graaff (1989). Plates of transformed protoplasts were incubated at $37^{\circ} \mathrm{C}$ in the dark until the first microcolonies were visible. Spores from these microcolonies were removed and streaked out to a single colony on MM plates (minimal medium, $1.2 \%$ agar, and appropriate supplements). Spores from a single colony were transferred into $100 \mu \mathrm{l}$ of water and subsequently propagated and tested by Southern blot for integration of the transforming plasmid.

\section{Measurement of hyphal biomass in liquid culture.}

T. yallundae conidia were collected from TWA plates and washed several times with sterile water. The conidia were diluted to $5 \times 10^{5}$ conidia per $\mathrm{ml}$ in liquid Czapek-Dox supplemented media. Polyamines were diluted to the appropriate concentration in Czapek-Dox supplemented liquid media, $80 \mu \mathrm{l}$ was added to each well of a 96-well, flat-bottomed Nunc microtiter plate, and eight replicates were prepared for each concentration. Eighty microliters of conidial suspension was subsequently added to each well. The plates were incubated at $18^{\circ} \mathrm{C}$ with shaking at $200 \mathrm{rpm}$. The absorbance of each well of the microtiter plate was measured daily with a plate reader (Tecan, Weymouth, U.K.) at a wavelength of $600 \mathrm{~nm}$. Protein was measured in samples with the Bio-Rad Protein Assay Kit (Hemel, Hempsted, U.K.) according to the manufacturer's instructions.

\section{ODC enzyme assay.}

Fungal ODC activity was measured, as described by Stevens et al. (1976), following the release of ${ }^{14} \mathrm{CO}_{2}$ from $\left(1-{ }^{14} \mathrm{C}\right)$ ornithine. Spores were harvested from confluently sporulating Czapek-Dox-V8 plates and washed extensively with sterile distilled water. They were suspended in $100 \mathrm{ml}$ of CzapekDox liquid media at $1 \times 10^{7}$ per $\mathrm{ml}$ and incubated at $25^{\circ} \mathrm{C}$ with shaking. Material was harvested by filtration through Miracloth. Samples were ground to a fine powder in liquid nitrogen with glass beads, then resuspended in 2 to $3 \mathrm{ml}$ of extraction buffer $(10 \mathrm{mM}$ potassium phosphate; $2 \mathrm{mM}$ dithiothreitol; $1 \mathrm{mM} \mathrm{MgCl} 2 ; 0.1 \mathrm{mM}$ EDTA; and $0.1 \mathrm{mM}$ pyridoxal phosphate, $\mathrm{pH}$ 7.6) and vortexed briefly. The resulting extract was centrifuged at $25,000 \times g$ to remove cell debris, then desalted to remove other decarboxylase substrates by buffer exchange in a Nap 10 column (Amersham Pharmacia Biotech) according to the manufacturer's instructions. Reactions contained $50 \mathrm{mM}$ Tris; $0.05 \mathrm{mM}$ ornithine; $0.32 \mathrm{mM}$ pyridoxal phosphate; 0.125 $\mathrm{mCi}{ }^{14} \mathrm{C}$-ornithine, $\mathrm{pH} 8.0$; and $0.2 \mathrm{ml}$ of extract in a final volume of $0.4 \mathrm{ml}$ were carried out in 14-ml snap-top Falcon tubes. $\mathrm{CO}_{2}$ was captured in suspended $0.5-\mathrm{ml}$ Eppendorf tubes containing $50 \mu \mathrm{l}$ 2-methoxyethanol-ethanolamine mixture (2:1 $\mathrm{vol} / \mathrm{vol})$. Reactions were incubated at $25^{\circ} \mathrm{C}$ for $30 \mathrm{~min}$ and stopped by the addition of $0.1 \mathrm{ml}$ of $50 \%$ trichloroacetic acid, then left for an additional $60 \mathrm{~min}$ to trap released ${ }^{14} \mathrm{CO}_{2}$. Trapped ${ }^{14} \mathrm{CO}_{2}$ was counted in a scintillation counter. Protein was measured, in 0.2-ml samples, with the Bio-Rad protein assay kit according to manufacturer's instructions.

\section{ACKNOWLEDGMENTS}

This work was supported by a grant from BBSRC and Zeneca Agrochemicals. We thank C. Aldam and J. Keon for running the sequencing gels.

\section{LITERATURE CITED}

Abrahamsen, M. S., and Morris, D. R. 1991. Regulation of expression of the ornithine decarboxylase gene by intracellular signal transduction pathways. Pages 107-119 in: Perspectives on Cell Regulation: From Bacteria to Cancer. M. Inouye, J. Campisi, D. D. Cunningham, and M. Riley, eds. Wiley-Liss, New York.

Bagni, N., Malucelli, B., and Torrigiani, P. 1980. Polyamines, storage substances and abscisic acid-like inhibitors during dormancy and very early activation of Helianthus tuberosus tuber tissues. Physiol. Planta. 49:341-345.

Bailey, A. N., Mueller, E., and Bowyer, P. 2000. Ornithine decarboxylase of Stagonospora (Septoria) nodorum is required for virulence towards wheat. J. Biol. Chem. 275:14242-14247.

Birnboim, H. C., and Doly, J. 1979. A rapid alkaline extraction method for the isolation of plasmid DNA. Nucleic Acids Res. 7:1513-1522.

Brawley, J. V., and Ferro, A. J. 1979. Polyamine biosynthesis during germination of yeast ascospores. J. Bacteriol. 140:649-654.

Carroll, A. M., Sweigard, J. A., and Valent, B. Improved vectors for selecting resistance to hygromycin. 1994. Fungal Genet. Newsl. 41:23.

Choih, S.-J., Ferro, A. J., and Shapiro, S. K. 1978. Relationship between polyamines and macromolecules in germinating yeast ascospores. J. Bacteriol. 133:424-426.

Cohn, M. S., Tabor, C. W., and Tabor, H. 1978. Isolation and characterization of Saccharomyces cerevisiae mutants deficient in S-adenosylmethionine decarboxylase, spermidine and spermine. J. Bacteriol. 134:208-213.

De Graaff, L. H. 1989. The structure and expression of the pyruvate kinase gene of Aspergillus nidulans and Aspergillus niger. Ph.D. thesis. Agricultural University, Wageningen, The Netherlands.

Deacon, J. W. 1973. Pseudoparenchyma produced by Cercosporella herpotrichoides in culture. Trans. Br. Mycol. Soc. 60:537-545.

Fitt, B. D. L., Goulds, A., and Polley, R. W. 1988. Eyespot (Pseudocercosporella herpotrichoides) epidemiology in relation to prediction of disease severity and yield loss in winter wheat: A review. Plant Pathol. 37:311-328.

Fonzi, W. A., and Sypherd, P. S. 1987. The gene and the primary structure of ornithine decarboxylase from Saccharomyces cerevisiae. J. Biol. Chem. 262:10127-10133.

Guevara-Olvera, L., Xoconostle-Cazares, B., and Ruiz-Herrera, J. 1997 Cloning and disruption of the ornithine decarboxylase gene of Ustilago maydis: Evidence for a role of polyamines in its dimorphic transition. Microbiology 143:2237-2245.

Guye, M. G., Vigh, L., and Wilson, J. M. 1986. Polyamine titer in relation to chill-sensitivity in Phaseolus sp. J. Exp. Bot. 37:1036-1043.

Havis, N. D., Walters, D. R., Foster, S. A., Martin, W. P., Cook, F. M., and Robins, D. J. 1994a. Fungicidal activity of 3 putrescine analogs. Pestic. Sci. 41:61-69.

Havis, N. D., Walters, D. R., Martin, W. P., Cook, F. M., and Robins, D. J. 1994b. Fungicidal activity of 3 putrescine analogs. Pestic. Sci. 41: 71-76.

Hickok, N. J., Seppanen, P. J., Gunsalus, G. L., and Janne, O. A. 1987. Complete amino-acid-sequence of human ornithine decarboxylase deduced from complementary DNA. DNA 6:179-187.

Mackintosh, C. A., and Walters, D. R. 1997. Fungicidal activity of two spermidine analogues. J. Phytopathol. 145:43-45.

Mattern, I. E., and Punt, P. J. 1988. A vector of Aspergillus transformation conferring phleomycin resistance. Fungal Genet. Newsl. 35:25.

Michael, A. J., Furze, J. M., Rhodes, M. J. C., and Burtin, D. 1996. Molecular cloning and functional identification of a plant ornithine decarboxylase cDNA. Biochem. J. 314:241-248.

Nicholson, P., Rezanoor, H. N., Simpson, D. R., and Joyce, D. 1997. Differentiation and quantification of the cereal eyespot fungi Tapesia yallundae and Tapesia acuformis using a PCR assay. Plant Pathol. 
46:842-856.

Palavan, N., and Galston, A. W. 1982. Polyamine biosynthesis and titer during various developmental stages of Phaseolus vulgaris. Physiol. Planta. 55:438-444.

Paulus, T. J., Kiyono, P., and Davies, R. H. 1982. Polyamine-deficient Neurospora crassa mutants and synthesis of cadaverine. J. Bacteriol. 152:291-297.

Pegg, A. E., and McCann, P. P. 1982. Polyamine metabolism and function. Am. J. Physiol. 243:212-221

Ruiz-Herrera, J. 1993. The role of polyamines in fungal cell differentiation. Arch. Med. Res. 24:263-265.

Ruiz-Herrera, J. 1994. Polyamines, DNA methylation, and fungal differentiation. Crit. Rev. Microbiol. 20:143-150.

Sambrook, J., Fritsch, E. F., and Maniatis, T. 1989. Molecular Cloning: A Laboratory Manual. Cold Spring Harbor Laboratory, Cold Spring Harbor, NY, U.S.A.

Scott, P. R., and Hollins, T. W. 1974. Pathogenic variation in Pseudocercosporella herpotrichoides. Ann. Appl. Biol. 94:297-300.

Sikora, L., and McDougall, K. J. 1978. The regulation of ornithine decarboxylase in Neurospora crassa. Exp. Mycol. 2:352-358.

Slocum, R. D., Kaur-Sawhney, R., and Galston, A. W. 1984. The physiology and biochemistry of polyamines in plants. Arch. Biochem. Biophys. 235:283-303.

Smith, T. A. 1985. Polyamines. Ann. Rev. Plant Physiol. 36:117-143.

Sneath, P. H. A. 1955. Putrescine as an essential growth factor for a mu- tant of Aspergillus nidulans. Nature 175:818.

Specht, C. A., DiRusso, C. C., Novotny, C. P., and Ullrich, R. C. 1982. A method for extracting high-molecular-weight deoxyribonucleic-acid from fungi. Anal. Biochem. 119:158-163.

Stevens, L., and Winther, M. D. 1979. Spermine, spermidine and putrescine in fungal development. Adv. Microbial Physiol. 19:63-148.

Stevens, L., McKinnon, I. M., and Winther, M. 1976. Polyamine and ornithine metabolism during the germination of conidia of Aspergillus nidulans. Biochem. J. 158:235-241.

Tabor, C. W., and Tabor, H. 1976. Polyamine biosynthesis. Ann. Rev. Biochem. 45:285-306.

Tabor, C. W., and Tabor, H. 1985. Polyamines in microorganisms. Microbiol. Rev. 49:81-99.

Von Ropenack, E., Parr, A., and Schulze-Lefert, P. 1998. Structural analyses and dynamics of soluble and cell wall-bound phenolics in a broad spectrum resistance to the powdery mildew fungus in barley. J. Biol. Chem. 273:9013-9022.

Walters, D. R. 1989. Polyamines and plant disease. Plants Today January-February:22-26.

Walters, D. J. 1995. Inhibition of polyamine biosynthesis in fungi. Mycol. Res. 99:129-139.

Williams, L. J., Barnett, G. R., Ristow, J. L., Pitkin, J., Perriere, M., and Davies, R. H. 1992. Ornithine decarboxylase gene of Neurospora crassa: Isolation, sequence, and polyamine-mediated regulation of its messenger RNA. Mol. Cell. Biol. 12:347-359. 